Vol. 2 | No. 4 | 2021 | Hal. 287-293

\title{
SOSIALISASI DIGITAL MARKETING BAGI PELAKU UMKM DI DESA
}

\author{
Mohammad Rizal*, Azza Nur Laila, Nurain Ali, Nuzulur Rohmah, Moh Hafi Nasil \\ Maula, Rifatul Waasiah \\ Fakultas Ekonomi dan Bisnis, Universitas Islam Malang \\ *korespondensi email: mohammadrizal@unisma.ac.id
}

\begin{abstract}
ABSTRAK
Salah satu bidang usaha yang tetap konsisten dan berkembang dalam perekonomian nasional salah satunya adalah Usaha Mikro, Kecil, dan Menengah (UMKM). Dengan maraknya pertumbuhan usaha saat ini persaingan pasarpun semakin ketat.Peralihan tren pemasaran dari konvensional (offline) ke media online menyebabkan para pelaku UMKM yang tidak memanfaatkan potensi digital marketing kehilangan kesempatan untuk lebih mengembangkan bisnisnya. Sosialisasi ini diikuti oleh 21 (Dua puluh Satu) orang para pelaku UMKM yang berada di Kecamatan Pujon Kabupaten Malang. Para pelaku UMKM di sini masih kurang inovatif dalam mengembangkan usahanya. Umumnya, mereka belum menggunakan daya pikir yang kreatif untuk menggunakan digital marketing dengan memanfatkan jejaring sosial sebagai media pemasaran.Sosialisasi ini dilakukan dengan dengan tujuan untuk membentuk usaha kecil yang produktif dan mengikuti perkembangan zaman. Para peserta sosialisasi sangat antusias dengan materi dan pemaparan yang disampaikan.Kondisi ini diharapkan dapat memotivasi para pelaku UMKM mempraktekkan ilmu yang didapat, sehingga usahanya semakin berkembang dan dapat bersaing pada pasar yang lebih luas.
\end{abstract}

Kata Kunci: UMKM; sosial media; digital marketing; e-commerce

\section{PENDAHULUAN}

Kehidupan masyarakat saat ini tidak dapat dipisahkan dengan keberadaan kegiatan Usaha Mikro, Kecil, dan Menengah (UMKM) (Rizal et al., 2019). Selain dianggap mempunyai peran yang signifikan terhadap peningkatan perekonomian di Indonesia, UMKM juga dapat menyerap tenaga kerja dalam skala yang cukup besar. Pertumbuhannya yang pesat berdampak pada semakin tingginya persaingan usaha yang terjadi.

Menurut Machmud (2013) diperkirakan sebagian besar para pelaku usaha mikro bergerak pada sektor yang konvensional, dan peran kelompok usaha UMKM ini mempunyai peran yang penting dalam perekonomian di Indonesia. Hal ini memanifestasikan gejala informalisasi perekonomian, bahwa tenaga kerja yang tidak berhasil diserap oleh sektor formal akan bergeser ke sektor konvensional (Kurniawan et al., 2021). Sejalan dengan pertumbuhan bisnis usaha dalam skala mikro, kecil, dan menengah, kemajuan teknologi juga mengalami perkembangan yang sangat pesat, saat ini internet merupakan salah satu fasilitas kemajuan teknologi yang dapat digunakan untuk melakukan pemasaran produk secara online yang juga dikenal dengan istilah digital marketing, baik melalui media sosial ataupun e-commerce (Febrian et al., 2021; Lestari et al., 2021). Sehingga untuk dapat tetap eksis dan bersaing, UMKM harus lebih terbuka untuk dapat mengikuti perkembangan zaman agar dapat mengembangkan usahanya secara global. 
UMKM merupakan pemeran penting dalam pengembangan ekonomi lokal di berbagai sektor serta dalam pemberdayaan masyarakat, karena bisnis ini sangat berperan dalam menciptakan lapangan kerja. Kegiatan ini menggambarkan usaha ekonomi produktif yang berdiri sendiri, baik dilakukan secara kelompok maupun individu (Kadeni \& Srijani, 2020; Tedjasuksmana, 2014). Para pengusaha UMKM pastinya memiliki metode sendiri dalam memikat pelanggan. Aktivitas pemasaran bisnis harus terus dikembangkan sesuai perkembangan zaman sehingga konsumen terbiasa dan memiliki atensi terhadap usaha tersebut. Pesatnya perkembangan dunia digital saat ini sangat berperan dalam ekspansi usaha, baik bagi individu maupun usaha yang lebih besar.

Pada masa sekarang, kepiawaian dan pengetahuan para pelaku UMKM di daerah terhadap perkembangan teknologi informasi masih sangat kurang, khususnya para pelaku UMKM di Desa Manting umumnya, di Kecamatan Pujon khususnya. Akibatnya, mereka seringkali mengalami hambatan dalam mengelola bisnisnya. Kondisi ini dapat dilihat dari sistem pemasaran yang belum menggunakan teknologi informasi yang sesuai. Padahal, dewasa ini hampir seluruh pelaku bisnis telah menggunakan fasilitas internet untuk melakukan produk melalui digital marketing, dengan memanfaatkan media sosial.

Para pelaku UMKM hendaknya dapat menguasai perkembangan teknologi yang semakin modern (Saleh \& Hadiyat, 2016). Dengan melakukan pemasaran melalui media sosial, tentu akan menjadi penunjang kesuksesan bisnis, menarik minat konsumen, sehingga jangkauan pasarpun semakin luas. Oleh sebab itu perlu adanya peningkatan pengetahuan tentang perkembangan teknologi informasi seperti digital marketing dengan memanfaatkan media sosial, serta aplikasi teknologinya bagi usaha kecil, khususnya para pelaku UMKM di Desa Manting Kecamatan Pujon, Kota Malang, dalam mengembangkan usaha kedepannya. Darmawan (2012) mengatakan bahwa teknologi informasi merupakan produk rekayasa manusia terhadap metode penyampaian informasi dari pengirim ke penerima yang menyebabkan lebih luas, lebih cepat sebarannya, serta dapat disimpan lebih lama. Dengan melakukan pemasaran melalui media sosial, tentu akan menjadi penunjang kesuksesan bisnis, menarik minat konsumen, sehingga dapat menjangkau pasar yang lebih luas.

Maraknya pertumbuhan usaha berhasil memperketat persaingan pasar saat ini. Situasi ini dengan tegas memaksa para pelaku usaha untuk dapat mengoptimalkan strategi pemasaran serta produktivitasnya. Sehingga dengan semakin ramainya persaingan pasar, usahanya tetap bertahan bahkan berkembang di tengah banyak munculnya peluang usaha lain yang semakin ramai dan kreatif. Dengan semakin derasnya perkembangan teknologi digital saat ini dunia bisnis tentu saja akan merasakan imbasnya. Kecenderungan pemasaran dunia kini beralih dari pemasaran konvensional (offline) menjadi serba kontemporer (online). Melalui pemanfaatan teknologi informasi yang saat ini sedang tren, salah satunya yaitu media sosial, pemilihan digital marketing dapat menjadi alasan utama bagi para pelaku usaha mikro untuk menggunakan media online sebagai jalan keluar efektif dan efisien yang dibutuhkan untuk dapat memperluas jangkauan bisnisnya.

Menurut Manshur, (2020) dan Oktaviani \& Rustandi (2018) Purwana ES, Rahmi, dan Aditya (2017), digital marketing merupakan usaha untuk memperkenalkan sebuah merek dengan menggunakan media digital yang dengan tepat dapat menjangkau konsumen. Internet tentunya akan memiliki peran penting dalam hal ini. Selain itu, dari banyak sisi, kemudahan konsumen untuk mencari dan mendapatkan produk dapat dilakukan hanya melalui ponsel, internet dan sosial media. Di sisi lain, pebisnis juga dapat dengan mudah memantau dan menyediakan kebutuhan sesuai keinginan pembeli.

Menjadi sebuah kewajiban bagi para pegiat usaha untuk memahami fungsi dan manfaat penggunaan media sosial yang sedang populer ini. Instagram, Twitter, Youtube juga WhatsApp merupakan beberapa media sosial yang sering digunakan pengusaha modern 
sebagai media promosi, serta aplikasi e-commerce seperti Tokopedia, Shopee, serta Lazada yang sering digunakan untuk memasarkan produk. Jika dilihat dari sudut pandang konsumen, penggunaan informasi teknologi komunikasi akan memberikan beberapa keuntungan, termasuk di dalamnya efisiensi, kenyamanan, informasi menyeluruh mengenai produk, harga yang bersaing, potongan harga, dan perbedaan produk (Indrayani, 2012). Untuk menjaring calon konsumen sesuai target dan pasar yang ingin dicapai, para pelaku bisnis dapat dengan mudah memanfaatkan fasilitas yang disediakan oleh media sosial ataupun e-commerce secara optimal untuk memasarkan produknya.

\section{METODE}

Kegiatan ini dilaksanakan di Dusun Manting Tawangsari Kec. Pujon Kab. Malang pada Bulan Agustus 2021. Peserta yang terlibat sebanyak 12 orang yang merupakan Fakultas Ekonomi dan Bisnis Prodi Akuntansi dan Perbankan Syari'ah. Instrumen yang digunakan selama kegiatan berangsung adalah, infocus yang digunakan untuk menampilkan slide presentasi, laptop, jaringan internet, situs media sosial. Metode kegiatan pengabdian dilakukan dengan ceramah, praktik dan diskusi. Kegiatan tersebut dapat dilihat pada table berikut ini:

Tabel 1. Pelaksanaan Kegiatan

\begin{tabular}{cll}
\hline No & \multicolumn{1}{c}{ Kegiatan } & \multicolumn{1}{c}{ Materi } \\
\hline \multirow{2}{*}{1} & Sosialisasi Digital & - Pasar Online \\
& Marketing & - Promosi melalui social media \\
2 & UMKM Jamu & - Memperbarui pengemasan \\
& & - Memperluas jaringan pemasaran \\
3 & UMKM Krupuk petulo & - Memperbarui pengemasan \\
& & - Memperluas jaringan pemasaran \\
\hline
\end{tabular}

\section{HASIL DAN PEMBAHASAN}

\section{Kegiatan Sosialisasi Digital Marketing}

Kegiatan 'Sosialisasi Digital Marketing pada Usaha Mikro, Kecil, dan Menengah (UMKM) di Desa Tawangsari' telah dilaksanakan pada hari Jum'at, 6 Agustus 2021 yang bertempat di kantor Tawangsari setempat. Dalam sosialisasi yang dilakukan, Sasaran kegiatan sosialisasi ini yakni para pengusaha UMKM yang ada di Desa Tawangsari. Penetapan sasaran ini merupakan suatu upaya dalam menyampaikan wawasan serta pemahaman kepada para pelaku usaha tentang manfaat media sosial serta kegunaan pemasaran secara digital untuk mengembangkan usaha mereka. Secara resmi, pengertian usaha mikro, kecil, menengah diatur dalam Undang-Undang nomor 20 Tahun 2008. Yang menyatakan bahwa setiap usaha diberikan batasan tertentu sehingga ada kategori tertentu dalam menentukan apakah usaha tersebut termasuk ke dalam usaha mikro, kecil, maupun menengah. Usaha mikro berdasarkan undang-undang ini yakni usaha produktif milik perorangan atau badan usaha perorangan.

Kriteria UMKM menurut undang-undang ini, Berdasarkan pengamatan yang dilakukan terhadap pengusaha UMKM di lokasi sosialisasi didapat bahwa level penggunaan teknologi informasi para pelaku UMKM di kecamatan Pujon, masih berada pada tahapan dasar, yaitu mengenal dan mengoperasikan. Terdapat fakta bahwa para pelaku UMKM ini belum memahami keuntungan menggunakan pemasaran secara digital dalam menjalankan usahanya. Sedangkan dalam dunia bisnis, penjualan produk termasuk faktor yang sangat penting dalam memajukan usaha. 
Kegiatan UMKM memberikan dampak bagi kehidupan masyarakat dengan konsep kemandiriannya, serta menjadi pangkal dalam berkreasi. Derasnya perkembangan arus teknologi dan informasi, serta dengan semakin leluasanya persaingan dagang saat ini mengakibatkan meningkatnya pemahaman konsumen akan variatifnya produk-produk barang jasa yang dapat dipilih. Kemajuan dunia bisnispun terkena imbas dengan kemajuan teknologi dunia digital. Kecenderungan pemasaran di dunia beralih dari secara bertemu langsungberubah menjadi secara online (modern). Pada hakekatnya konsep pemasaran digital marketing ini bukanlah sepenuhnya hadir untuk menggantikan konsep pemasaran konvensional yang ada, melainkan keduanya muncul untuk saling mengisi peran satu sama lain.

Pada era digital sekarang ini, memasarkan bisnis dengan menggunakan internet merupakan sesuatu yang dianggap mutlak dalam dunia globalisasi, yakni pemasaran (marketing) melalui media sosial, yang selain mudah digunakan, efisien, juga biayanya yang tergolong murah. Karena, dengan kemudahan yang tersedia pada platform media sosial, promosi dapat dilakukan secara gratis dan efisien, tentu saja aktor-aktor dalam usaha mikro ini mulai mendapatkan instrumen penting dalam memajukan serta pengembangan usahanya. Secara global berkembangnya teknologi informasi memberikan dampak yang besar pula kepada perkembangan UMKM.

Dalam sosialisasi ini, penulis memberikan pemaparan mengenai pentingnya peran digital marketing bagi perkembangan bisnis saat ini. Dengan konsep digital marketing bentuk promosi yang diimplementasikan tidak saja lagi bersifat strategi satu arah, namun telah menjadi hubungan dua arah. Jika dilihat dari sudut pandang konsumen, penggunaan informasi teknologi komunikasi akan memberikan beberapa keuntungan, baik potongan harga, kemudahan pencarian produk, efisien dan sebagainya, persaingan antar pelaku usaha yang membuat pasar semakin berkembang serta produk yang semakin bervariasi. Akan tetapi, faktanya masih banyak dari para pelaku usaha mikro ini menutup diri untuk berkembang. Mereka tetap melakukan pemasaran secara konvensional, yaitu hanya menjual produknya kepada para konsumen yang ada di sekitar wilayah pasarnya. Dengan berkembangnya teknologi informasi saat ini hendaknya para pelaku UMKM harus mengedapankan inovasi, pembaharuan pasar, serta orientasi yang dilakukan secara global mengingat faktor-faktor tersebut sangat menentukan keberhasilan persaingan dalam pasar global.

Pemasaran yang dilakukan secara digital merupakan istilah lazim terhadap semua usaha penjualan yang dilakukan dengan sitem online. Berbisnis dengan memanfaatkan akses internet secara digital melalui media sosial, situs web, juga aplikasi e-commerce dilakukan agar terhubung dengan pelanggan dan calon pelanggan dengan lebih cepat dan mudah. Lemahnya pengetahuan peserta sosialisasi terhadap pembuatan strategi pemasaran menggunakan internet menjadikan mereka belum memanfaatkan fitur pemasaran digital yang disediakan, termasuk di dalamnya penggunaan media sosial dan aplikasi e-commerce lainnya. Padahal, saat ini sangat besar manfaat dan peranan penggunaan media sosial untuk menarik konsumen, serta memperluas jangkauan bisnisnya. Sehingga segmen pasar yang diraihpun semakin luas.

Pada kesempatan sosialisasi ini, para pelaku usaha mikro inipun akhirnya dapat melakukan praktek langsung dalam menggunakan sosial media untuk memasarkan dagangannya Setelah mengikuti sosialisasi tentang digital marketing, diharapkan para pelaku UMKM di Desa Tawangsari ini mampu: a. Memanfaatkan teknologi informasi semaksimal mungkin sehingga dapat membantu mengembangkan usahanya dan dapat bersaing secara global dengan para pelaku usaha lain. b. Secara aktif memanfaatkan 
digital marketing baik melalui media sosial maupun aplikasi e-commerce lainnya sehingga dapat menjangkau pasar serta menarik konsumen secara lebih luas.

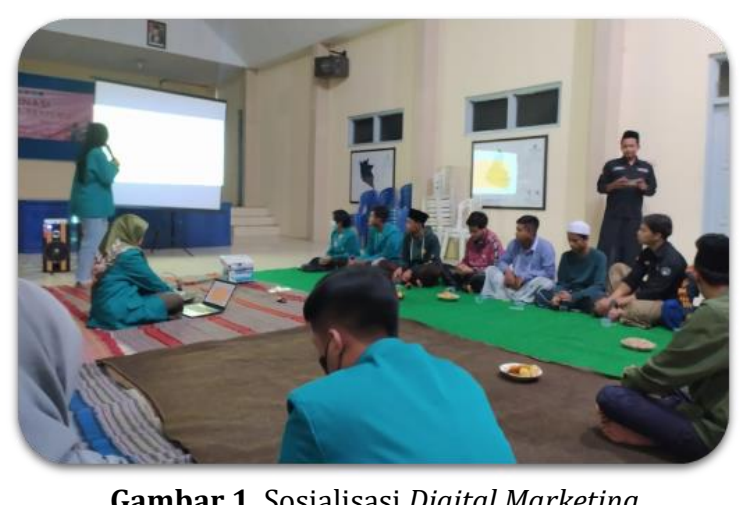

Gambar 1. Sosialisasi Digital Marketing

\section{UMKM Jamu}

Jamu beras kencur adalah obat tradisional yang membuatanya berbentuk cairan langsung minum. Umumnya jamu beras kencur atau jamu tradisional ini dibuat dengan mengacu pada resep warisan leluhur. Jadi bisa membuat jamu sendiri di rumah menggunakan bahan-bahan nya seperti campuran beras, gula merah, kunyit, kencur, asam jawa. jamu beras kencur adalah jamu sebagai penambah stamina dan nafsu makan. Jamu beras kencur juga dapat mengatasi masalah pencernaan, sesak napas, pilek, hingga sakit kepala. Dan jamu tidak memerlukan pembuktian ilmiah sampai uji klinis di laboratoriumSebuah ramuan tradisional bisa dikatakan jamu apabila keamanan dan khasiatnya telah terbukti berdasarkan pengalaman langsung pada manusia selama ratusan tahun.

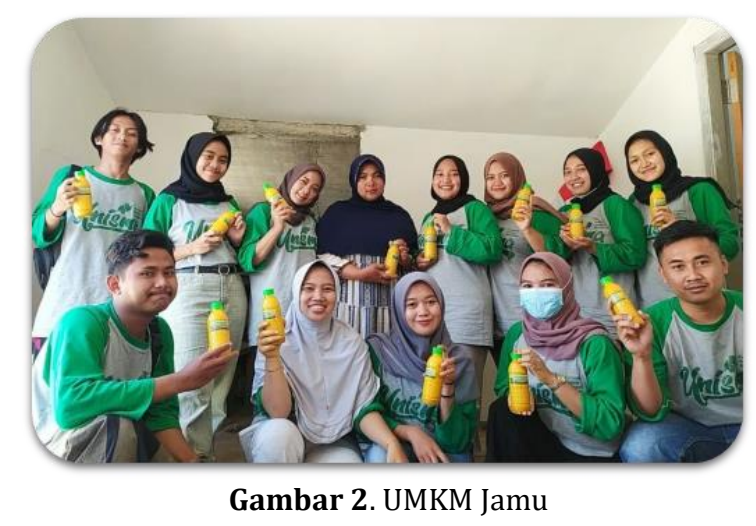

\section{UMKM Krupuk Petulo}

Kerupuk pertulo adalah kerupuk yang terbuat dari adonan tepung beras dan tepung kanji dan di tambah penambah rasa dan pewarna makanan Kerupuk petulo ini berasal dari desa tawangsari dusun manting. Setalah di jadikan satu bahan-bahan tersebut langsung di cetak Kemudian dikukus setelah itu dijemur hingga kering. Pengeringan dengan terik matahari. Kerupuk mentah yang kering ini siap digoreng kapan saja agar bisa menjadi kerupuk yang siap dihidangkan. 


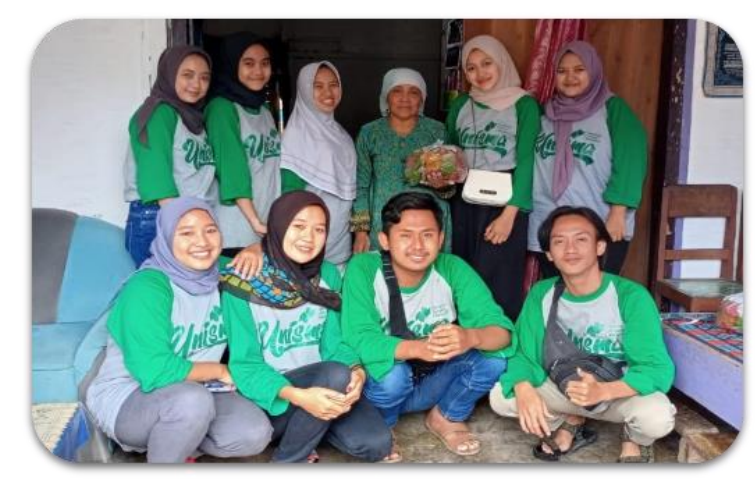

Gambar 3. UMKM Krupuk Petulo

\section{KESIMPULAN}

Para pelaku UMKM yang ada di daerah, khususnya pelaku UMKM di Kecamatan Pujon ini, masih belum mengembangkan usahanya secara luas. Masih banyak pelaku UMKM menutup diri untuk berkembang. Mereka hanya menjual produknya kepada para konsumen yang ada di sekitar wilayah pasarnya. Sosialisasi ini dilakukan untuk memberikan pemahaman bagi para pelaku UMKM untuk lebih mengedepankan inovasi dan orientasi global mengingat kedua faktor tersebut sangat menentukan keberhasilan dalam bersaing di pasar global. Keunggulan bersaing bagi pelaku bisnis khususnya UMKM sangat ditentukan oleh kemampuannya dalam mengantisipasi globalisasi. Dalam sosialisasi ini penulis juga memaparkan pentingnya peran digital marketing bagi perkembangan bisnis. Dengan konsep digital marketing, bentuk promosi yang diimplementasikan tidak lagi berupa program satu arah yang dilakukan perusahaan untuk konsumen, namun sudah menjadi interaksi dua arah.

Optimalisasi penggunaan digital marketing pada UMKM khususnya media sosial perlu dilakukan mengingat manfaat positif yang diperoleh para pelaku usaha demi memajukan usahanya. Para pelaku UMKM khususnya di daerah Manting hendaknya harus sering diberikan sosialisasi ataupun pengenalan terhadap perkembangan teknologi informasi, serta dorongan dari pihak terkait, baik itu dari pemerintah ataupun pihak akademisi, untuk membantu UMKM agar bisa bertahan dan lebih banyak meraih pendapatan dari hasil produksi yang mereka buat agar bisa menggerakan roda perekonomiannya dengan pencapaian yang lebih maksimal untuk menaikkan taraf kehidupannya.

Kegiatan serupa dapat dilakukan kembali dengan khalayak sasaran yang lebih luas, mengingat banyaknya pelaku UMKM di daerah khususnya Desa Manting masih banyak yang belum memahami penggunaan dan manfaat digital marketing terhadap perkembangan bisnisnya, sehingga bisnis mereka terkesan jalan di tempat. Diharapkan agar kegiatan lainnya bisa melakukan pengkajian lebih analitis terkait dengan perilaku pasar dan konsumen di era pemasaran secara digital. Hal ini tentu saja sangat berguna dalam menambah perbendaharaan ilmu dalam bidang pemasaran yang sesuai dengan perkembangan teknologi yang terkini.

Bagi Warga Masyarakat Desa Tawangsari program-program yang telah dilaksanakan mahasiswa KKN semoga dapat diteruskan dan dikembangkan serta dimanfaatkan untuk kepentingan masyarakat setempat serta dapat melanjutkan program-program yang berkelanjutan.

\section{UCAPAN TERIMA KASIH}

Ucapan terima kasih bisa disampaikan kepada LPPM UNISMA yang memberikan kesempatan kepada kami untuk melakukan kegiatan KKN serta Kepala Desa Desa Tawangsari, Kecamatan Pujon Kabupaten Malang yang telah memberi izin pada kami untuk melakukan pengabdianmasyarakat. 


\section{DAFTAR RUJUKAN}

Darmawan, D. (2012). Pendidikan Teknologi Informasi Dan Komunikasi. PT. Remaja Rosdakarya.

Febrian, A., Lina, L. F., Safitri, V. A. D., \& Mulyanto, A. (2021). Pemasaran digital dengan memanfaatkan landing page pada perusahaan start-up. Jurnal Inovasi Hasil $\begin{array}{lll}\text { Pengabdian Masyarakat } & \text { (JIPEMAS), }\end{array}$ https://doi.org/10.33474/jipemas.v4i3.10103

Indrayani, H. (2012). Penerapan Teknologi Informasi dalam Peningkatan Efektivitas, Efisiensi dan Produktivitas Perusahaan. Jurnal El-Riyasah, 3(1), 48-56. https://doi.org/10.24014/jel.v3i1.664

Kadeni, \& Srijani, N. (2020). Peran UMKM (Usaha Mikro Kecil Menengah) Dalam Meningkatkan Kesejahteraan Masyarakat. EQUILIBRIUM : Jurnal Ilmiah Ekonomi Dan Pembelajarannya, 8(2), 191-200. https://doi.org/10.25273/equilibrium.v8i2.7118

Kurniawan, E., Nofriadi, \& Maharani, D. (2021). Sosialisasi digital marketing dalam upaya peningkatan penjualan produk UMKM. Jurnal Pemberdayaan Sosial Dan Teknologi Masyarakat, 1(1), 31-36. https://doi.org/10.54314/jpstm.v1i1.542

Lestari, R. I., Santoso, D., \& Indarto, I. (2021). Meningkatkan literasi keuangan digital pada pelaku UMKM melalui sosialisasi gerakan nasional non-tunai. Jurnal Inovasi Hasil $\begin{array}{lll}\text { Pengabdian Masyarakat } \quad \text { (JIPEMAS), } & \text { 378-390. }\end{array}$ https://doi.org/10.33474/jipemas.v4i3.10947

Machmud, A. (2013). Strategi Pemberdayaan Usaha Mikro Kecil Menengah Melalui Peran Lembaga Keuangan Syariah dalam Upaya Pengentasan Kemiskinan di Indonesia. Semnas Fekon, 600-615. http://repository.ut.ac.id/5078/1/fekon2012-52.pdf

Manshur, M. I. (2020). Peran Digital Marketing dalam Membangun Brand Awareness Busana Hijab Syar'i SI.SE.SA. Jurnal Ilmu Komunikasi Politik Dan Komunikasi Bisnis, 4(2), 113130. https://jurnal.umj.ac.id/index.php/perspektif/article/view/9420

Oktaviani, F., \& Rustandi, D. (2018). Implementasi Digital Marketing dalam Membangun Brand Awareness. PRofesi Humas : Jurnal Ilmiah Ilmu Hubungan Masyarakat, 3(1), 120. https://doi.org/10.24198/prh.v3i1.15878

Rizal, M., Mustapita, A. F., \& Kartika Sari, A. F. (2019). Pelatihan Untuk Pengajuan Pembiayaan Mudharabah Perbankan Syariah Sebagai Peningkatan Kinerja UMKM. Jurnal Inovasi Hasil Pengabdian Masyarakat (JIPEMAS), 3(1), 15-22. https://doi.org/10.33474/jipemas.v3i1.2569

Saleh, B., \& Hadiyat, Y. D. (2016). Use of Information Technology among Performers Micro Small Medium Enterprises in the Border Area (Study in Belu, East Nusa Tenggara). Journal Pekommas, 1(2), 141-152. https://doi.org/10.30818/jpkm.2016.2010204

Tedjasuksmana, B. (2014). Potret UMKM Indonesia Menghadapi Masyarakat Ekonomi Asean 2015. The 7th NCFB and Doctoral Colloquium 2014 Towards a New Indonesia Business Architecture Business And Economic Transformation Towards AEC 2015, 189-202. http://repository.wima.ac.id/id/eprint/982/1/ETR005 - B Bdianto Tedjasuksmana.pdf 